\title{
Comparison of Bactericidal Activity of Serum Collected from Typhoid Patients and Normal Human Against Salmonella typhi at Various Incubation Time
}

\author{
Mohammad Shahriar ${ }^{1}$, Luke Donald Halder ${ }^{1}$, Nayeema Nushrat ${ }^{1}$, \\ Mahboob Hossain ${ }^{1}$, A.N.M. Hamidul Kabir ${ }^{2}$ and Shaila Kabir ${ }^{3}$ \\ ${ }^{1}$ Department of Pharmacy, The University of Asia Pacific, Dhanmondi, Dhaka-1209, Bangladesh \\ ${ }^{2}$ Department of Applied Chemistry \& Chemical Engineering, Faculty of Engineering \& Technology, \\ University of Dhaka, Dhaka-1000, Bangladesh \\ ${ }^{3}$ Department of Pharmaceutical Chemistry, Faculty of Pharmacy, University of Dhaka, \\ Dhaka-1000, Bangladesh
}

\begin{abstract}
With an estimated 16-33 million cases of typhoid fever annually resulting in 500,000 to 600,000 deaths in endemic areas, the World Health Organization identifies typhoid, caused by the bacterium Salmonella enterica serovar typhi as a serious public health problem. Its incidence is the highest in children and young adults between 5 and 19 years old.

Susceptibility to the serum bactericidal system is a widespread characteristic of gram-negative bacteria. In addition to the many well-documented instances of enterobacterial susceptibility to complement, serum is known to possess bactericidal and bacteriolytic activity against susceptible representatives of practically every gram-negative genus so far examined. ${ }^{1}$ The bactericidal effect of normal human serum plays an important role in host defense against bacterial infection. This phenomenon has been widely noted and studied since the late $1800 \mathrm{~s}^{2}$ and has been shown to be complement mediated. ${ }^{3,4}$ Early colonization of the intestinal tract
\end{abstract}

Correspondence to:

Mohammad Shahriar

Tel: +88-02-9664953 ext. 146 ,

Mobile: +88-02-011-99-844-259

E-mail: shahriar_12@yahoo.com

Dhaka Univ. J. Pharm. Sci. 9(1): 65-67, 2010 (June) by commensally bacteria ensures that small quantities of antibodies directed against the surface antigens of many types of gram-negative bacteria are present in the blood and tissue fluids of humans ${ }^{5}$ and a variety of animals ${ }^{6}$. Thus, IgM and IgG antibodies directed against surface antigens of E. coli ${ }^{7}$ and other enterobacteria $^{8}$ as well as against Neisseria species. ${ }^{7,9}$ However, the development of the humoral immune response to $\mathrm{O}, \mathrm{H}$, and $\mathrm{Vi}$ antigens of Salmonella typhi has been regularly demonstrated during and after typhoid fever. ${ }^{10}$ As a result, the sera of typhoid fever patients had been shown to harbor antibodies against $\mathrm{O}, \mathrm{H}$, and $\mathrm{Vi}$ antigens. ${ }^{11-13}$ Therefore, sera from patient diagnosed with typhoid can provide the source for anti- S. typhi antibodies, along with the proteins of complement system. ${ }^{1}$

In the current study, bactericidal activity of $S$. typhi infected human serum against $S$. typhi was investigated. The requirement of complement pathways in serum mediated killing of $S$. typhi is also examined by means of inactivating both classical and alternative pathways of $S$. typhi infected human sera.

The S. typhi bacterial strain was collected from the Microbiology Department of Children's Hospital, Dhaka. The bacterial strain was collected as red colony with black centre on a Xylose Lysine 
Dechocolate (XLD) agar plate. The strain was tested using gram staining and serological studies. The organism was maintained at $4^{0} \mathrm{C}$ in XLD slant for not more than 15 days. Stock culture was streaked on a XLD plate and incubated at $37^{\circ} \mathrm{C}$ overnight. S. typhi from the overnight subculture was then transferred into $100 \mathrm{ml}$ of normal saline, shaken to break the clumps and then adjusted to desired concentration by serial dilution.

Blood samples from nine healthy human with proper medical history were collected aseptically by venipuncture. Blood samples were kept in test tubes at $4^{0} \mathrm{C}$ overnight, centrifuged at $4000 \mathrm{rpm}$ (Eppendorf AG 22331 Hamburg, Germany) for $10 \mathrm{~min}$. The sera were separated and stored at minus $20^{\circ} \mathrm{C}$ in small aliquots. Sera from nine $S$. typhi infected patients who were diagnosed with typhoid fever were collected from Holy Family Red Crescent Hospital and Ibn Sina Diagnostic Centre. The sera were stored at minus $20^{\circ} \mathrm{C}$ in small aliquots.

The serum bactericidal assay for all nine $S$. typhi infected human sera and nine normal human sera were carried out according to Taylor and Kroll. ${ }^{14}$ Bacterial cell suspension of $4.43 \log _{10} \mathrm{CFU} / \mathrm{ml}$ was treated with $40 \%$ human serum (this was found to be the optimum concentration) and incubated at $37^{\circ} \mathrm{C}$ for $15 \mathrm{~min}, 30 \mathrm{~min}, 45 \mathrm{~min}, 60 \mathrm{~min}$ and $90 \mathrm{~min}$. The treated bacterial suspension was then spreaded on bismuth sulphite agar plate (stored at $4^{\circ} \mathrm{C}$ for 2 days before use) and the colonies were counted after overnight incubation. $60 \mu \mathrm{l}$ bacterial cell suspensions (4.43 $\log _{10} \mathrm{CFU} / \mathrm{ml}$ ) was added to $40 \mu \mathrm{l}$ physiological saline which was used as positive control. $60 \mu \mathrm{l}$ physiological saline was added to $40 \mu \mathrm{l}$ serum which was used as negative control. Role of complement pathways on the serum bactericidal activity was determined following the method described by several investigators. ${ }^{1}$ Both classical and alternative pathways of nine $S$. typhi infected sera were inactivated by heating at $56^{\circ} \mathrm{C}$ for $30 \mathrm{~min}$. After the heat treatment, the sera were subjected to serum bactericidal assay.

The mean values of the $\log _{10}$ CFUs of $S$. typhi observed after serum bactericidal assay at various incubation time in per $\mathrm{ml}$ of bacterial cell suspension treated with each of nine $S$. typhi infected human sera, nine normal human sera, and nine heat-treated S. typhi infected human sera were calculated and plotted against various incubation time (Figure 1).

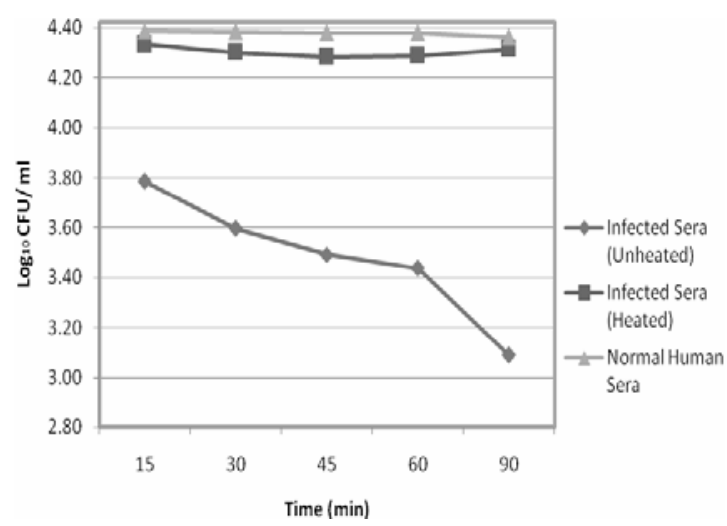

Figure 1. Mean bactericidal activity $\left(\log _{10} \mathrm{CFU} / \mathrm{ml}\right)$ of $S$. typhi infected sera, normal human sera, and heat-treated S. typhi infected sera

The mean growth of S. typhi in the presence of infected human sera showed decline than the positive control starting from $3.79 \log _{10} \mathrm{CFU} / \mathrm{ml}$ after $15 \mathrm{~min}$ incubation time and $3.09 \log _{10} \mathrm{CFU} / \mathrm{ml}$ after $90 \mathrm{~min}$ incubation time as shown in Figure 1.

In the present study bactericidal activity of nine $S$. typhi infected human sera was examined against $S$. typhi. From this study it has been observed that $S$. typhi infected serum mediated killing increased with the increase of incubation time and showed maximum activity after 90 min incubation time (Figure 1).

The requirement for complement pathways in serum mediated killing of $S$. typhi was also examined by inactivating both classical and alternative pathways with heat treatment. Each of the nine $S$. typhi infected human serum was exposed to $56^{\circ} \mathrm{C}$ for 30 min according to Taylor ${ }^{1}$ before mixing with the bacterial suspension. This treatment resulted in complete loss of serum bactericidal activity in most of the cases. This finding suggests the requirement of complement system pathways in serum mediated killing of S. typhi. Similar findings were observed in case of other organisms. There is a large body of 
evidence indicating than the complement system is an important component of the host defense against infection with gram-negative bacteria. ${ }^{14}$

The requirement of the anti- S. typhi antibodies and the consequent activation of classical activation was investigated by examining the bactericidal activity of nine normal human sera, depriving of antiS. typhi antibodies, against S. typhi. This study was unable to show any considerable killing of bacterial cell suspension, indicating the necessity of anti- $S$. typhi antibodies in the serum for classical pathway of activation and subsequent killing by Membrane Attack Complex (MAC) formation.

\section{REFERENCES}

1. Taylor, P. W. 1983. Bactericidal and bacteriolytic activity of serum against gram-negative bacteria. Microbiol. Mol. Biol. Rev. 47, 46-83.

2. Buchner, H. 1889. Uber die bakterientotende Wirkung des zellenfreien Blutserums. Zentralbl Bakt Parasitenkd Infektionskr Hyg Erste Abt Orig Reihe A Med Mikrobiol Parasitol. 5, 817-823.

3. Inoue, K., Yonemasu, K., Takamizawa, A., and Amano, T. 1968. Studies on the immune bacteriolysis. XIV. Requirement of all nine components of complement for immune bacteriolysis. Biken. J. 11, 203-206.

4. Sansano, M. Jr., Reynard, A. M., and Cunningham, R. K. 1985. Inhibition of serum bactericidal reaction by lipopolysaccharide. Infect Immun. 48, 759-762.

5. Mason, T. G., and Richardson, G. 1981. Escherichia coli and the human gut: some ecological considerations. J. Appl. Bacteriol. 1, 1-16.
6. Šterzl, J., Kostka, J., and Lanc, A. 1962. Development of bactericidal properties against gram-negative organisms in the serum of young animals. Folia Microbiol (Prague). 72, 162174.

7. Cohen, I. R. and Norins, L. C. 1966. Natural human antibodies to gram-negative bacteria: immunoglobulins G, A, and M. Science. 152, 1257-1259.

8. Michael, J. G., and Rosen, F. S. 1963. Association of "natural" antibodies to gram-negative bacteria with the Xlmacroglobulius. J. Exp. Med. 118, 619-626.

9. Goldkchneider, I., Gotschlich, E. C., and Artenstein, M. S. 1969. Human immunity to the meningococcus. II. Development of natural immunity. J. Exp. Med. 129, 13271348.

10. Kumar, R., Malaviya, A. N., Murthy, R. G., Venkataraman, M., and Mohapatra, L. N. 1974. Immunological Study of Typhoid: Immunoglobulins, C3, Antibodies, and Leukocyte Migration Inhibition in Patients with Typhoid Fever and TAB-Vaccinated Individuals. Infect. Immun. 10, 1219-1225.

11. Hornick, R. B., Greisman, S. E., Woodward, T. E., Dupont, H. L., Dawkins, A. T., and Snyder, M. J. 1970. Typhoid fever, pathogenesis and immunological control, parts 1 and 2. N. Engl. J. Med. 283, 686-691, 739-746.

12. Rajagopalan, P., Kumar, R., and Malaviya, N. 1981. Immunological studies in typhoid fever. 1. Immunoglobulins, C3, antibodies, rheumatoid factor and circulating immune complexes in patients with typhoid fever. Clin. Exp. Immunol. 44, 68-73.

13. Ortiz, V., Isibasi, A., García-Ortigoza, E., and Kumate, J. 1989. Immunoblot detection of class-specific humoral immune response to outer membrane proteins isolated from Salmonella typhi in humans with typhoid fever. J. Clin. Microbiol. 27, 1640-1645.

14. Taylor, P. W., and Kroll, H. P. 1983. Killing of an encapsulated strain of Escherichia coli by human serum. Infect. Immun. 39, 122-131. 